\title{
TAX EVASION THROUGH OFFSHORE COMPANIES: HOW IMPORTANT THE PHENOMENON IS?
}

\author{
Romualdas Ginevičius ${ }^{1}$, Manuela Tvaronavičienè $\dot{2}^{2}$ \\ Vilnius Gediminas Technical University, Sauletekio al. 11, LT-10223 Vilnius-40, Lithuania \\ E-mail: rector@adm.vtu.lt ${ }^{1}$,manuela@post.omnitel.net ${ }^{2}$
}

Received: 25 Sept 2003; accepted 3 Nov 2003

\begin{abstract}
The aim of the paper is to elaborate phenomenon of offshore activity. In the article principles and conditions of offshore companies' performance have been discussed and the most popular areas of offshore economical activity analyzed. Authors' view to efficiency of Lithuanian government's attempts to restrict usage of offshore zones has been presented.
\end{abstract}

Keywords: offshore zones, transfer pricing, tax evasion

\section{Introduction}

The topic of the article touches topical issues related with tax evasion via transfer pricing. Opinions can be found that because of increasing amounts of countries adopting transfer pricing, it has become the most important international tax issue [1]. Other authors emphasize, that the first concern is to give tax authorities comprehensive guidance due to restrict tax reduction through offshore companies [2].

Hence, article aims to give extended description of offshore companies and mechanism of transfer pricing in the most popular economic activities.

Lithuanian government made the first attempt by adopting resolution No. 888 in 1997 [3]. The underlying idea was to impose to tax cash flows, which have been directed to countries or zones listed. That hit hard Lithuanian firms, which used tax advantages, offered by so called "tax heavens". Despite the fact, that offshore activity was restricted, we need to admit, that still it haven't been stopped as Lithuanian firms have access to "tax heavens" through other countries, with Russia being the most popular among them. This circumstance has conditioned closer look to the country, which has been made through presented case study.

\section{What company is considered as the offshore one?}

The offshore (offshore -'outside of borders') - the legal person registered in jurisdiction with the preferential taxation, at absence of the currency control. It is the company which does not conduct economic activities in the country of the registration, and owners of these companies - non-residents of these countries. Basis of occurrence of the offshore companies are the jurisdictions of the countries, it is in part or the companies completely releasing from the taxation which are doing not conduct business in the country of registration. It is important to notice, that the preferential taxation of offshore exists only regarding realization of activity outside of the country of registration. For high-grade work of the offshore in 
any other country it is required international agreement on avoidance of the double taxation of the given country with the country of registration of the offshore. Otherwise, the offshore is exposed to the taxation of the country where it conducts the activity.

At the moment in the world it is totaled about 60 countries providing tax privileges for the offshore companies. Their activity actually is accountable to nobody, in the majority of "tax harbors" the annual reporting is reduced to transfer of the fixed gathering.

\section{Main economical areas of offshore activity}

\subsection{Intermediary in trade}

The basic sphere of application of offshore enterprisesintermediaries is the foreign trade operations. At export the offshore company buys the exported goods under the lowest price which can be specified without excitation of suspicion, and then resells these goods to the final buyer already under the world price, retaining not assessed by taxes and not under inspection to local authorities a difference. We shall consider a simple example; the offshore company has bought from the manufacturer the goods for 100 dollars. In Russia, for example these goods can be sold for 200 dollars. If to import it at the price of 199 dollars, the Russian enterprise will pay the profit tax only from 1 dollar that is very favorable.

\subsection{Owner of expensive property}

At purchase of any expensive property (a country house, a site of the ground, a yacht, the private plane or other subjects not the first necessity), it is necessary to solve the problem on the proprietor of this property. Expensive property can be bought not by the investor, but through the company controllable by him.

\subsection{Owner and the licensor of a trade mark and copyrights}

The trade mark can be registered on the offshore company (or to sell to it already registered sign). Further the offshore company on the basis of license contracts will give you (or to your companies) the right to use it is familiar for the certain payment. Thus royalties (a payment for the right of use of a trade mark) can not only increase an account part of balance (thus reducing the tax), but also to provide a legal opportunity to transfer currency abroad.

Copyrights to books, audiovisual products and other objects of intellectual property have in a context of tax planning one conclusive advantage before all other things on light: their price cannot be established proceeding from any uniform rules. For this reason payments for copyrights are very convenient way of lawful reduction of taxes and export of the capital.

\subsection{Investment activity}

The offshore company (or a network of the offshore companies) can become a convenient reloading point of the capital on his way to the new investment project. First, the capital can be accumulated in such company without taxes. Second, having provided anonymity of possession of the offshore company, it is possible to provide thus that the new investment project has not been connected in any way to old. Thirdly, anywhere there is no such maneuverability and flexibility of movement of investment resources, as in the offshore financial centers.

Through the offshore company it is possible to trade in securities or to be engaged in currency dealing if there is a corresponding experience. Through the offshore company it is possible to speculate in the market of the real estate. The potential of investment maneuverability inherent in the offshore companies will hardly be compared with someone else's.

\subsection{Ship-ownership}

Many offshore centers give the courts going under their flag. The most popular countries for registration of yachts: Isle of Man, Malta, Panama, Cyprus, Liberia, Gibraltar [4]. Instead of high-grade taxes offshore ship registers raise an easy payment for the tonnage or simply the duty on prolongation of registration. If activity is connected to trading navigation use of the offshore company as the shipowner can the same as and in a case with a yacht, it is essential to optimize tax payments.

\subsection{Insurance activity}

The Offshore insurance company allows to export from country the capital, not having paid thus of practically any taxes. It usually doesn't need to meet capital-risk requirements.

\subsection{Offshore banking}

The offshore bank is the bank registered in one of "offshore zones" (as a rule, the small island states). Offshore banks have the following basic distinctive features: - has no right to work with residents of the 
country of registration of bank (the most important distinctive feature); - the required size of the paid authorized capital for them is less, than in the advanced countries of the West, and in the majority of other countries; - the bank can receive full tax exemption; - as a rule, laws on obligatory reserves, rules of crediting and realization of investments less strict, than in other countries; - the bank can be created rather quickly; - At establishment of bank use of nominal shareholders and directors (though true owners should be all the same known to local authorities - differently to bank will not give the license) is supposed; - the currency control over operations outside of the country of registration almost always is absent. From the point of view of corporate structure, the bank is that other, as usual corporation which has received the bank license. The corporation because in the form of companies already almost nobody creates banks - interferes with this the unlimited responsibility of founders inherent in companies. For some of the mentioned operations the offshore bank is simply necessary, for others enough for the simple offshore company; however the offshore bank will add operations flexibility. If it is necessary to have the foreign account for itself or for the offshore company for confidential international payments it is possible to open accounts directly in offshore bank. Technically money will be on one of corresponding accounts in foreign bank and for the benefit of the third parties the bank will carry out all payments, operating with the rest on a corresponding account, if necessary on its own behalf that is important, if it is necessary to keep confidentiality of payment. In addition to this, the offshore bank can open the number, coded accounts, accounts with a pseudonym, etc.

The offshore bank can open accounts and carry out operations in any currencies of the CIS - the full analogy to Baltic banks. The offshore bank becomes very convenient tool by development of new services for bank clients, as for example, plastic cards, game in international market Forex (currency dealing), the letters of credit confirmed with the first class banks in the West, etc. Thus, offshore banks can be used for very wide spectrum of financial operations.

Table 1. Characteristics of the most popular offshore zones [5]

\begin{tabular}{|c|c|c|c|c|c|c|c|}
\hline JURISDICTION & $\begin{array}{l}\text { BRITISH } \\
\text { ISLANDS }\end{array}$ & BAHAMAS & PANAMA & IRELAND & CYPRUS & DELAWER & $\begin{array}{l}\text { DELAWER } \\
\text { CORPORA- } \\
\text { TION }\end{array}$ \\
\hline Official language & English & English & $\begin{array}{l}\text { English, } \\
\text { Spanish }\end{array}$ & English & $\begin{array}{l}\text { Greek, } \\
\text { Turkish }\end{array}$ & English & English \\
\hline Profit Tax & NO & NO & NO & NO & $4.25 \%$ & NO & NO \\
\hline Known Owners & NO & NO & NO & Yes & Yes & NO & NO \\
\hline Shares for inspection & Yes & Yes & Yes & $\begin{array}{l}\text { Difficult } \\
\text { usage }\end{array}$ & NO & NO & NO \\
\hline Minimal Capital & NO & NO & NO & UKF 2 & CYP 1000 & NO & USD 1 \\
\hline Standard capital & USD 50000 & USD 5000 & USD 10000 & $\operatorname{IRF} 1$ & CYP 5000 & NO & USD 150000 \\
\hline Currency & Any & Any & Any & Any & CYP & USD & Any \\
\hline $\begin{array}{l}\text { Minimal number of } \\
\text { shareholders }\end{array}$ & 1 & 1 & 1 & 1 & 2 & 2 & 1 \\
\hline Minimal number of Directors & 1 & 1 & 3 & 2 & 1 & 1 & 1 \\
\hline Corporate directors & Yes & Yes & NO & NO & Yes & NO & NO \\
\hline Secretary & NO & NO & Yes & Yes & Yes & NO & Yes \\
\hline Public registration of Directors & NO & NO & Yes & Yes & Yes & NO & NO \\
\hline $\begin{array}{l}\text { Public registration of } \\
\text { Shareholders }\end{array}$ & NO & NO & NO & Yes & Yes & NO & NO \\
\hline Annual Audit & NO & NO & NO & Yes & Yes & Yes & Yes \\
\hline Annual balance requirements & NO & NO & NO & Yes & Yes & Yes & Yes \\
\hline
\end{tabular}




\section{Conditions of economical activity in the most popular offshore zones}

Below various characteristics of the most popular offshore zones are presented (Table 1).

From presented data we can conclude that if the company working in country with double taxation avoidance treaty adopted is registered e.g. in Cyprus, it will only pay the symbolical tax. Therefore we can claim that it is very profitable to do so.

On Table 2, there is a summary of main recipients of extra-EU inflows from offshore centers. The biggest

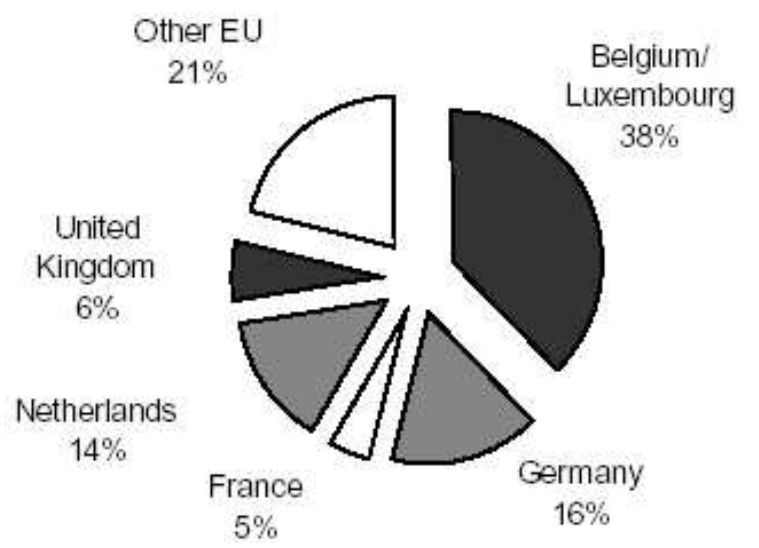

Table 2. Main recipients of extra-EU inflows from offshore centers, 1996-1999 Cumulated flows [6]

share is given to Belgium and Luxemburg and Germany. Together other EU nations share 21 per cent in total. We need to notice, that, surprisingly to our opinion to find out, that such well developed countries, as United Kingdom and France share only 6 and 5 per cent respectively.

\section{Russia - Case study}

One of the best examples to show offshore business can be described on Russian 'rich' business going offshore.

Cyprus has emerged as one of the gateways through which wealthy Russian investors have moved assets totaling to $\$ 300 \mathrm{bn}$ abroad.

According to Russia's ministry of economic development and trade, about half of the total of between \$210bn and \$230bn that left the country during 1990s reforms was linked to crime.
According to the International Monetary Fund, perhaps \$170bn was moved offshore between 1994 and 2001.

One of the reasons for capital flights has been to protect money gained in the fire sale of Russia's state assets, in most cases to a handful of obligations with good connections to the administration of the president Boris Yeltsin, following the collapse of Communist rule in 1991.

Current Russia president has been encouraging the flight capital to return to Russia for use by domestic companies. Along with slight changes in the competitiveness of Russia's saving rates, this policy has been effective, with a net $\$ 4.6 \mathrm{bn}$ returning in the first six months of the year. However, the Central Bank estimates that up to $\$ 8.6 \mathrm{bn}$ may have left the country in the second half of 2003. This assessment follows the arrest in October of Mikhail Khodorkovsky.

The services typically offered Russians are banking facilities initially, with Latvia, Cyprus and Switzerland being key routes for the money to pass through [7]. The growth in offshore bank deposits matches that of deposits in domestic banks, which amounted to \$29.8bn at the end of May 2003.

\section{Regulation of the offshore business}

In the world three basic systems of the taxation of the profit, definitions of the rate of the tax differing on a way on the part of the profit distributed and unpaid on dividends are applied [8].

Classical system. According to it the special tax to the distributed part of the profit is absent. Legal and physical persons are in unequal tax conditions as individual persons pay also surtax. The classical system is applied in Australia, Luxembourg, Netherlands, New Zealand, Spain, Sweden, Switzerland and the USA. This system is one with "the separate rate of the tax" (split rate). The distributed and unpaid profit in a considered case has the various rate of the tax. The separate rate is applied in Austria, Finland, Greece, Japan, and Norway. Here tax position of individual investors and corporations is in part leveled. The share of the tax paid by the company from the profit is financed (compensated) to final shareholders at reception of the dividend. The double taxation thus manages to be avoided. This system is applied in Belgium, Canada, Denmark, France, Ireland, Italy, Turkey and the Great Britain.

In Germany there is the combined system including 
elements of two last: the rate of the tax separate, however final shareholders receive indemnification as decrease in surtaxes for the sum of the taxes paid from the profit of the company at distribution of dividends. In result in this country position individual and institutional investors equally. So, in corporate sector within the limits of the given jurisdiction usually there are various ways of elimination of the double taxation. Accordingly the same income cannot be assessed twice - at a stage of distribution of the dividend and at a stage of his transfer in the income of firm - the final shareholder. At carrying out of commercial operations internationally the problem of elimination of the double taxation becomes aggravated. In this case, elimination of the double taxation demands special settlement at an interstate level. Really, the incomes "cleared" of taxes in one jurisdiction, at receipt in another risk to be again enlisted in assessed profit. The tax burden can considerably increase because of the tax "at a source" which in many cases reaches $30 \%$. Therefore all states of the world apply this or that system of elimination of the double taxation of the incomes received from abroad. She is based both on the national legislation and on the international agreements on elimination of the double taxation (double taxation avoidance treaties).

Another type of taxation involves system of the tax credit without a delay (credit system without deferral). It is applied by some countries, including: USA, the Great Britain and Germany, at the taxation of incomes of foreign branches of the domestic-owned firms which are not being legal persons. At this system the tax credit is given irrespective of, incomes have been transferred home or reinvested in the foreign state. The tax credit means that the tax raised from the parent company is reduced for the sum of the taxes paid abroad on incomes received there. The tax credit is carried out within the limits of the rate of the profit tax established in the given jurisdiction.

Tax the credit with a delay (credit system with deferral). The tax credit of this type concerns to incomes of the branches being independent legal persons. It provides full or partial compensation of the following kinds of the taxes raised by the foreign states: - Taxes "at a source" on the transferred dividends which have been paid in the country - a source of incomes; - the certain share of the foreign profit taxes paid abroad.

This share is compensated (financed) after dividends have been repatriated by parent firm. Here there is "delay" of indemnification till the moment of receipt of incomes. In USA, Great Britain, Germany, Belgium,
Ireland, Italy, and some other countries the tax credit is given Japan on a unilateral basis, i.e. for all resident firms. In Austria, Denmark, Luxembourg - on the basis of corresponding position in the agreement on elimination of the double taxation.

System of tax exemption (exemption system) provides full exception of foreign profits of the taxation or in the country of parent firm, or in a country-source. Tax exemption occurs usually on a bilateral basis at presence of the corresponding agreement. The given system is applied by such countries, as Australia, Luxembourg, France, Netherlands, and Switzerland. At calculations with this group of the countries the special attention should be given that conditions of transactions fell under action of tax agreements. In some special cases one more approach - exception (subtraction) of taxes (tax deduction) is applied.

\section{Conclusions}

As a whole, creation of the offshore companies is the effective tool of tax planning and currency activity. In the future, with rise of industrial production and the further concentration of the capital, the probability is that new splash in creation of the offshore companies can take place.

Methods and ways of the international tax planning, the characteristic of the offshore enterprises presented in the paper testify, that for the enterprises there are various legal ways of optimization of a level of the taxation, not accompanying with the conflict to the law.

However the stated methods allow to draw simultaneously a conclusion and that optimization of a level of the taxation by means of the international tax planning and use of an offshore mode is rather qualified kind of the administrative activity, demanding participation of experts of a various structure, and also use of the information (especially legal) of the broad audience of sources.

Concrete methods and ways should get out each time individually, proceeding from features of the enterprise and its production, and also the purposes put by investors and management of the enterprise and other factors. Optimization of the taxation does not mean the conflict of the enterprise to the state. Final their long-term purposes coincide. The state is interested in development of the national enterprises. Therefore optimization of the taxation of the enterprise in essence represents the compromise between the purposes of the enterprise and the purposes of the state. 
Any attempts of government to restrict offshore activities of local firms couldn't be effective enough if, like in Lithuanian case, the third countries, such as e.g. Russia, leaves opportunity to use "tax heavens" legally. Therefore, improvement of business climate in own country should be emphasized due to restrict lure of offshore companies.

\section{References}

1. Ernst\&Young. Transfer pricing in the focus for MNEs. CMA Management, Feb2004, Vol.77 issue 9, p.9, 2/3p.
2. D.Endres, A.Oestreicher. International Tax Review, Mar2004, Vol.32 Issue 3, p. 137, 11p.

3. http://www.lrs.lt

4. Ebsco database: Business Source Premier.

5. OFFSHORE UPSTARTS By: Munich, Paula, eWeek, 15306283, 9/23/2002, Vol. 19, 38.

6. CIO Magazine, The Hidden Costs of Offshore Outsourcing, Sept. 2003).

7. Price Waterhouse Coopers: Banking Report.

8. “Offshoring: Is It a Win-Win Game?” McKinsey Global Institute, Aug. 2003. 